\title{
Karyotype analysis, DNA content and molecular screening in Lippia alba (Verbenaceae)
}

\author{
PATRÍCIA M.O. PIERRE ${ }^{1}$, SAULO M. SOUSA ${ }^{2}$, LISETE C. DAVIDE ${ }^{3}$, \\ MARCO A. MACHADO ${ }^{4}$ and LYDERSON F. VICCINI ${ }^{2}$ \\ ${ }^{1}$ Centro de Ciências Humanas e Naturais, Departamento de Ciências Biológicas, Universidade Federal do Espírito Santo, \\ Avenida Fernando Ferrari, 514, Bairro Goiabeiras, 29040-090 Vitória, ES, Brasil \\ ${ }^{2}$ Instituto de Ciências Biológicas, Departamento de Biologia, Universidade Federal de Juiz de Fora, \\ Campus Universitário, Rua José Lourenço Kelmer, s/n, Bairro São Pedro, 36036-900 Juiz de Fora, MG, Brasil \\ ${ }^{3}$ Departamento de Biologia, Universidade Federal de Lavras, Caixa Postal 3037, \\ Campus Universitário, 37200-000 Lavras, MG, Brasil \\ ${ }^{4}$ Embrapa Gado de Leite, Laboratório de Genética Molecular, Rua Eugênio do Nascimento, 610, \\ Bairro Dom Bosco, 36038-330 Juiz de Fora, MG, Brasil \\ Manuscript received on February 22, 2010; accepted for publication on September 10, 2010
}

\begin{abstract}
Cytogenetic analyses, of pollen viability, nuclear DNA content and RAPD markers were employed to study three chemotypes of Lippia alba (Mill.) (Verbenaceae) in order to understand the genetic variation among them. Different ploidy levels and mixoploid individuals were observed. This work comprises the first report of different chromosome numbers (cytotypes) in L. alba. The chromosome numbers of La2-carvone and La3-linalool chemotypes suggested that they are polyploids. Flow cytometric analysis showed an increase of nuclear DNA content that was not directly proportional to ploidy level variation. A cluster analysis based on RAPD markers revealed that La3-linalool shares genetic markers with La1-citral and La2-carvone. The analysis showed that the majority of genetic variation of La3-linalool could be a consequence of mixoploidy. Our data indicates that sexual reproduction among those three chemotypes is unlikely and suggests the beginning of reproductive isolation. The results demonstrated that chromosome analysis, nuclear DNA content estimation and RAPD markers constitute excellent tools for detecting genetic variation among L. alba chemotypes.
\end{abstract}

Key words: chemotype, cytogenetic, cytotype, DNA content, RAPD, Lippia alba.

\section{INTRODUCTION}

One of the central goals of evolutionary biology is to understand the origin of new lineages and species. Accordingly, there is an abiding interest in the processes by which biodiversity arises, and in elucidating the full spectrum of intrinsic mechanisms and extrinsic forces that shape the speciation process. Adaptations to heterogeneous environmental conditions include both genetic differentiation as well the expression of an alternative range of phenotypes, commonly known as "pheno-

Correspondence to: Lyderson Facio Viccini

E-mail: lyderson.viccini@gmail.com typic plasticity" (West-Eberhard 1989, Scheiner 1993, Jump and Penuelas 2005). Consequently, natural selection may lead to genes that determine complex character responses (Bradshaw 2006). However, the ability of a species to adapt to environmental changes is known to depend greatly on the genetic diversity available for traits subjected, or potentially subjected, to selection (Noel et al. 2007).

Studies on plants with medicinal interest have shown that some species exhibit striking variations in the composition of their essential oils, sometimes also with morphological variations (Theis and Lerdau 2003, 
Tavares et al. 2004). Consequently, the identification of chemotypes or chemical varieties can be based on their major chemical component. This phytochemical and morphological phenomenon can be observed in some Verbenaceae species (Bassole et al. 2003). Lippia alba (Mill.) N.E. Brown, which is commonly known as "cidreira" in Brazil, is a typical example (Zoghbi et al. 1998, Biasi and Costa 2003, Tavares et al. 2004). Lippia alba is used in folk medicine for gastrointestinal and respiratory disorders, and has anti-inflammatory, antimicrobial and antifungal properties (Biasi and Costa 2003). Many chemotypes of these species were described (Hennebelle et al. 2008), and a system to classify them on the basis of composition and possible common biosynthetic pathways among different oils was proposed (Hennebelle et al. 2006).

Three of these L. alba chemotypes, designated as La1-citral, La2-carvone and La3-linalool, were described by Tavares et al. (2004). They have different pharmacological activities and show some morphological differences, such as size of their mature plants and leaves, as well as growth habit. In addition, some authors reported that this species has a wide phenotypic plasticity resulted from adaptations to environmental conditions (Kumar and Dutt 1989, Sanders 2001). However, morphological, phytochemical and micropropagation studies carried out by Tavares (2003) demonstrated that differences among the chemotypes remained even under identical environmental conditions, evidencing a possible genetic control.

Various techniques have been used to explore and identify genetic traits that contribute to genetic differentiation and, in some cases, to reproductive isolation of the genotypes. In addition to cytogenetic analysis, which is a powerful tool for the identification of variations in chromosome number and structure, the study of nuclear DNA amounts by flow cytometry brings important information about genomic variations (Dolezel et al. 2007). According to Ohri (1998), there is a remarkable difference in genome size at the infrageneric level, which can be used to demarcate various taxa. Moreover, DNA markers, such as random amplified polymorphic DNA (RAPD), are also useful tools for understanding the relationships among different accessions and genotypes (Saxena and Chandra 2006, Sheidai et al. 2007).
This work describes the use of cytogenetic, cytometric and molecular tools to understand the genetic differences among three chemotypes of $L$. alba. We also investigated pollen viability and meiotic behavior, and discussed their consequence in the reproduction and genomic stability of these three chemotypes.

\section{MATERIALS AND METHODS}

Plant Material

Three individuals of each chemotype (La1-citral, La2carvone and La3-linalool) of Lippia alba were collected in three Brazilian States (Rio de Janeiro, Ceará and São Paulo, respectively) and cultivated in a greenhouse under the same environmental conditions. All individuals were analyzed according to the methodology described as follow. The voucher herbarium specimens were deposited at the Herbarium CESJ, Instituto de Biologia, Universidade Federal de Juiz de Fora, Minas Gerais, Brazil.

\section{Cytogenetic Analysis}

Young root tips were pre-treated with $0.003 \mathrm{M} 8$-hydroxyquinoline at $4{ }^{\circ} \mathrm{C}$ for $8 \mathrm{~h}$ and fixed in ethanol: acetic acid (3:1) at room temperature. They were then digested with Pectinex Novozymes (Bagsvaerd Denmark ${ }^{\circledR}$ ) at $34^{\circ} \mathrm{C}$ for $3 \mathrm{~h}$. Slides were prepared using cell dissociation (Carvalho and Saraiva 1993) and conventional squash technique. To determine the number of chromosomes, a minimum of fifty metaphase cells of each one of three individuals of each chemotype was analyzed.

Ten metaphase cells with spread chromosomes of both La1-citral and La2-carvone were used for karyotype analysis. Chromosomes were classified according to the arm ratio using standard nomenclature (Levan et al. 1964). The chromosome length range (CLR), karyotype formula (KF), number of chromosomes with secondary constriction (NSC), haploid genome total length (HGTL) and ideograms were obtained for La1-citral and La2-carvone chemotypes.

\section{Meiotic Analysis and Pollen Viability}

Flower buds of three individuals of each chemotype were collected and fixed in methanol: acetic acid (3:1) at $-20^{\circ} \mathrm{C}$. Slides were prepared using air-dry technique adapted for reduced flower sizes (Caixeta and Carvalho 
2001, Viccini et al. 2006). Approximately 40 anthers were excised from 12 flower buds and placed in a special microtube $(0.5 \mathrm{ml})$ with a nylon screen attached $(60 \mu \mathrm{m})$. The material was washed in distilled water to remove fixative. The adapted tube containing the anthers was immersed in enzymatic solution (Pectinex Novozymes, Bagsvaerd, Denmark ${ }^{\circledR}$ ) and incubated at $34^{\circ} \mathrm{C}$ for $20 \mathrm{~min}$. After enzymatic maceration, the anthers were washed in distilled water and mechanically fragmented with an adapted pin to remove the pollen mother cells (PMCs). The cellular suspension obtained was centrifuged at $2000 \mathrm{rpm}$ for $12 \mathrm{~min}$. For slide preparation, about six drops of the suspension were added to a clean slide. Slides were air-dried and stained with Giemsa solution for three min. Cell images were digitalized using Image Pro Plus software (Media Cybernetic $^{\mathrm{TM}}$, Silver Spring. MD, USA). A total of 966 meiotic cells were analyzed.

Pollen from individuals of each chemotype was analyzed. Flower buds were collected and slides were prepared using squash technique, and viability was estimated according to differential staining (Alexander 1980). Digital images were taken with the BX60 microscope (Olympus, Tokyo, Japan). Mean pollen viability of La1-citral, La2-carvone and La3-linalool chemotypes were compared using the Scott-Knott test at 5\% probability.

\section{FLOW CYTOMETRY ANALYSIS}

Seedlings of Pisum sativum were used as a standard sample (9.09 pg/2C) (Cavallini and Natali 1990). Young leaves $(30 \mathrm{mg})$ of three plants of each chemotype and $P$. sativum (internal standard) were collected and chopped with a razor blade in $50 \mu \mathrm{L}$ of LB01 extraction buffer and filtrated with a $50 \mu \mathrm{m}$ nylon mesh filter. $25 \mu \mathrm{L}$ of staining buffer containing $1 \mathrm{mg} / \mathrm{mL}$ propidium iodide and $5 \mu \mathrm{L}$ of RNase were added, and the suspension was left at room temperature for $60 \mathrm{~min}$ in the dark. For each sample, at least 10.000 nuclei were analyzed using a logarithmic scale display. The analysis was performed with a FacsCalibur cytometer (Becton Dickinson). Each flow cytometric histogram was saved using Cell Quest software and analyzed with WinMDI 2.8 software. The $2 \mathrm{C}$ DNA content of the sample was calculated as the sample peak mean, divided by the $P$. sativum peak mean and multiplied with the amount of $P$. sativum DNA. Only measurements with coefficient of variance (CV) less 3\% were taken into account. The $\mathrm{CV}$ was calculated using the following formula: standard deviation/peak mean X $100 \%$.

\section{RAPD ANALYSIS}

\section{NUCLEAR DNA EXTRACTION AND RAPD AMPLIFICATION}

Genomic DNA was isolated from young leaves of three individual plants of each chemotype using the CTAB (cetyltrimethyl-ammonium bromide) procedure (Doyle and Doyle 1987) with modifications. Samples were identified as La1-1, La1-2, La1-3 for La1-citral; La2-1, La2-2, La2-3 for La2-carvone, and La3-1, La3-2, La33 for La3-linalool chemotypes. Amplification reactions were performed using the procedure of Williams et al. (1990) with modifications. Reactions were carried out in volumes of $25 \mu \mathrm{L}$ containing $1 \times$ Taq polymerase buffer (10mM Tris- $\mathrm{HCl} \mathrm{pH} 8.0 ; 50 \mathrm{mM} \mathrm{KCl}$ ); $2 \mathrm{mM} \mathrm{MgCl}_{2}$; $0.1 \%$ Triton X-100; $0.2 \mathrm{mM}$ each of dATP, dTTP, dCTP and dGTP (Pharmacia); $4 \mathrm{mM}$ of 10-mer primer (Operon Technologies Inc., Alameda, CA, USA); 1 U of Taq DNA polymerase (Promega, Madison, WI); and 30ng of template DNA. Forty-seven 10-mer random primers were tested. The reactions were performed in the GeneAmp ${ }^{\circledR}$ PCR System 9700 thermal cycler (Applied Biosystems, Foster City, CA) with the follow, cycling parameters: DNA template denaturation at $94^{\circ} \mathrm{C}$ for 2 minutes, followed by 45 cycles of PCR amplification (denaturation for $1 \mathrm{~min}$ at $94^{\circ} \mathrm{C}$, primer annealing for $1 \mathrm{~min}$ at $36^{\circ} \mathrm{C}$ and extension for $1,5 \mathrm{~min}$ at $72^{\circ} \mathrm{C}$ ). A final incubation for $5 \mathrm{~min}$ at $72^{\circ} \mathrm{C}$ was performed to ensure complete primer extension reaction. Amplification products were resolved on $5 \%$ polyacrilamide gel using $1 \times$ TBE buffer (44.5mM Tris/Borate, 0.5mM EDTA, pH8.0). Gels were stained with $15 \%$, silver nitrate solution.

\section{RAPD DATA ANALYSIS}

DNA markers were scored for the presence (1) or absence $(0)$ of homologous bands. Band scoring was performed using the Scanalytics Co Software (Stratagene, San Diego, CA, USA). Only reproducible, strong and evident bands were considered. The genetic dissimilarities were estimated by Nei and Li (1979) using the software GENES (Cruz 2001, version 2004 2.1). Clus- 
ter analysis was performed with UPGMA (unweighted pair-group method using arithmetic averages) using the JMP Software, version 3.1.6.2 (SAS Institute).

\section{RESULTS}

\section{Mitotic Analysis And Nuclear DNA Content}

In the present study, different chromosome numbers were found for each one of the three L. alba chemotypes. The chromosome number found for all individuals of La1-citral was $2 n=30$ (Fig. 1), while all individuals of La2-carvone showed $2 n=60$ (Fig. 2). Curiously, all individuals of La3-linalool showed the same range of chromosomes numbers, from $2 n=12$ to $2 n=60$, in different cells from the same individual (Fig. 5-8). Figure 9 illustrates this variation for one individual analyzed, and show, cells with $2 n=44$ as the most frequently found. Similar results were observed for other two individuals analyzed.

Two and four chromosome pairs with secondary constrictions were observed in La1-citral and La2carvone, respectively (Table I, Figs. 3 and 4). The chromosome variation observed among cells of each one of the three individuals analyzed of La3-linalool hindered the construction of the ideogram and, as a consequence, the determination of chromosome length range (CLR), karyotype formula (KF), haploid genome total length (HGTL) and also the number of secondary constriction.

\section{TABLE I}

Chromosome number $(\mathrm{CN})$, chromosome length range (CLR), karyotype formula (KF), number of chromosomes with secondary constriction (NSC) and haploid genome total length (HTGL) of La1-citral and La2-carvone chemotypes.

\begin{tabular}{c|c|c}
\hline & La1-citral & La2-carvone \\
\hline $\mathrm{CN}$ & $2 \mathrm{n}=2 \mathrm{x}=30$ & $2 \mathrm{n}=4 \mathrm{x}=60$ \\
$\mathrm{CLR}$ & $2.04-4.27 \mu \mathrm{m}$ & $1.48-4.81 \mu \mathrm{m}$ \\
$\mathrm{KF}$ & $8 \mathrm{~m}+7 \mathrm{sm}$ & $18 \mathrm{~m}+11 \mathrm{sm}+1 \mathrm{st}$ \\
$\mathrm{NSC}$ & 4 & 8 \\
HTGL & $43.02 \mu \mathrm{m}$ & $84.67 \mu \mathrm{m}$ \\
\hline
\end{tabular}

m: metacentric, sm: submetacentric, st: subtelocentric.

The nuclear DNA content and coefficients of variance for La1-citral and La2-carvone chemotypes were $1.86 \mathrm{pg}(\mathrm{CV}=1,72)$ and $3.42 \mathrm{pg}(\mathrm{CV}=1,65)$, respectively. La3-linalool shows that DNA content from 2.05 to $3.41 \mathrm{pg}$ with $\mathrm{CV}=5,54$.
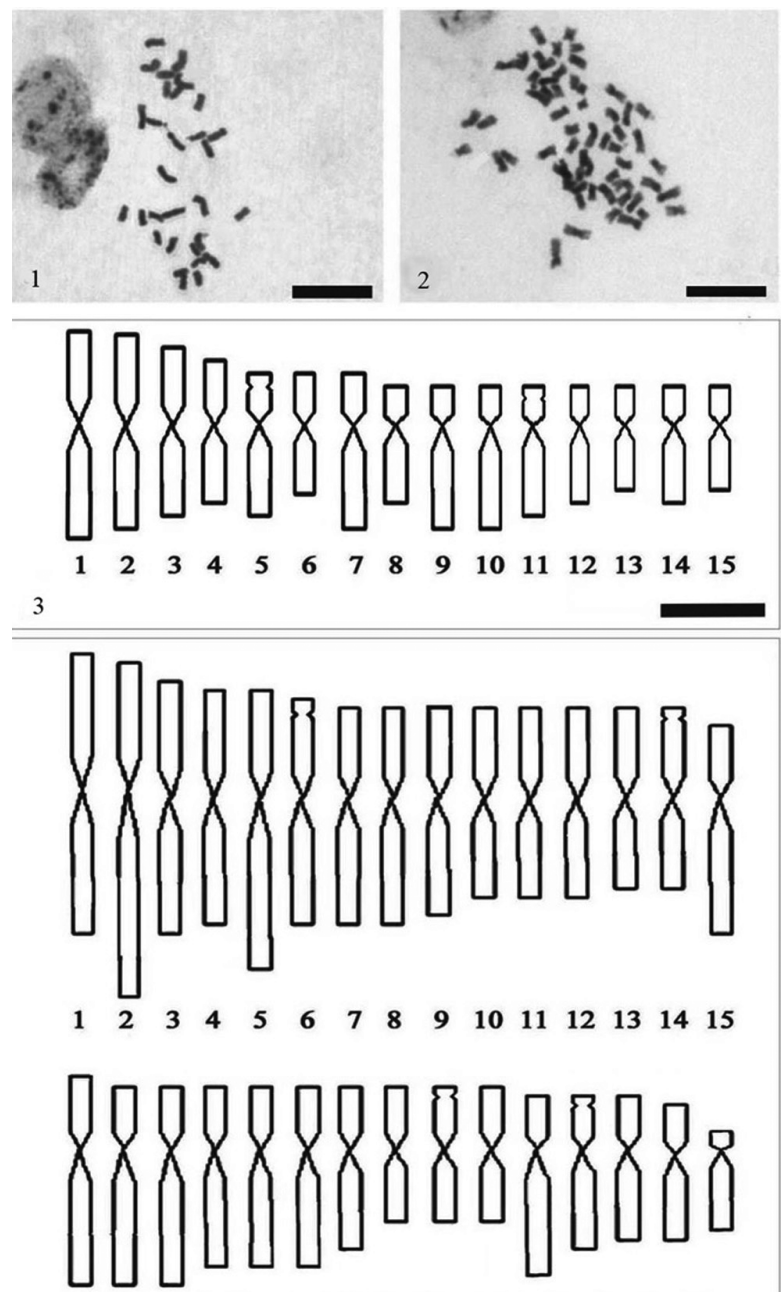

$\begin{array}{lllllllllllllll}16 & 17 & 18 & 19 & 20 & 21 & 22 & 23 & 24 & 25 & 26 & 27 & 28 & 29 & 30\end{array}$ 4

Figs. 1-4-Karyotype characteristics of L. alba chemotypes. Fig. 1: Metaphase chromosomes of La1-citral, $2 \mathrm{n}=2 \mathrm{x}=30$. Fig. 2: Metaphase chromosomes of La2-carvone, $2 n=4 x=60$. Fig. 3: Idiogram of La1-citral $(2 \mathrm{n}=30)$, chromosomes 5 and 11 show secondary constrictions. Fig. 4: Idiogram of La2-carvone $(2 \mathrm{n}=60)$, chromosomes $6,14,24$ and 27 show secondary constrictions. Scale bars = $10 \mu \mathrm{m}$ for figures 1 and 2; $2 \mu \mathrm{m}$ for figures 3 and 4 .

\section{Meiotic Analysis And Pollen Viability}

Several meiotic abnormalities were observed mainly in La2 and La3 chemotypes. La1-citral also showed some abnormalities ( $13.8 \%$ in 282 analyzed cells), but the majority of its cells showed 15 bivalents and regular meiosis. Univalents in diakinesis, early chromosome segregation in metaphase I, and also lagging chromosomes in anaphase I and telophase I were observed 

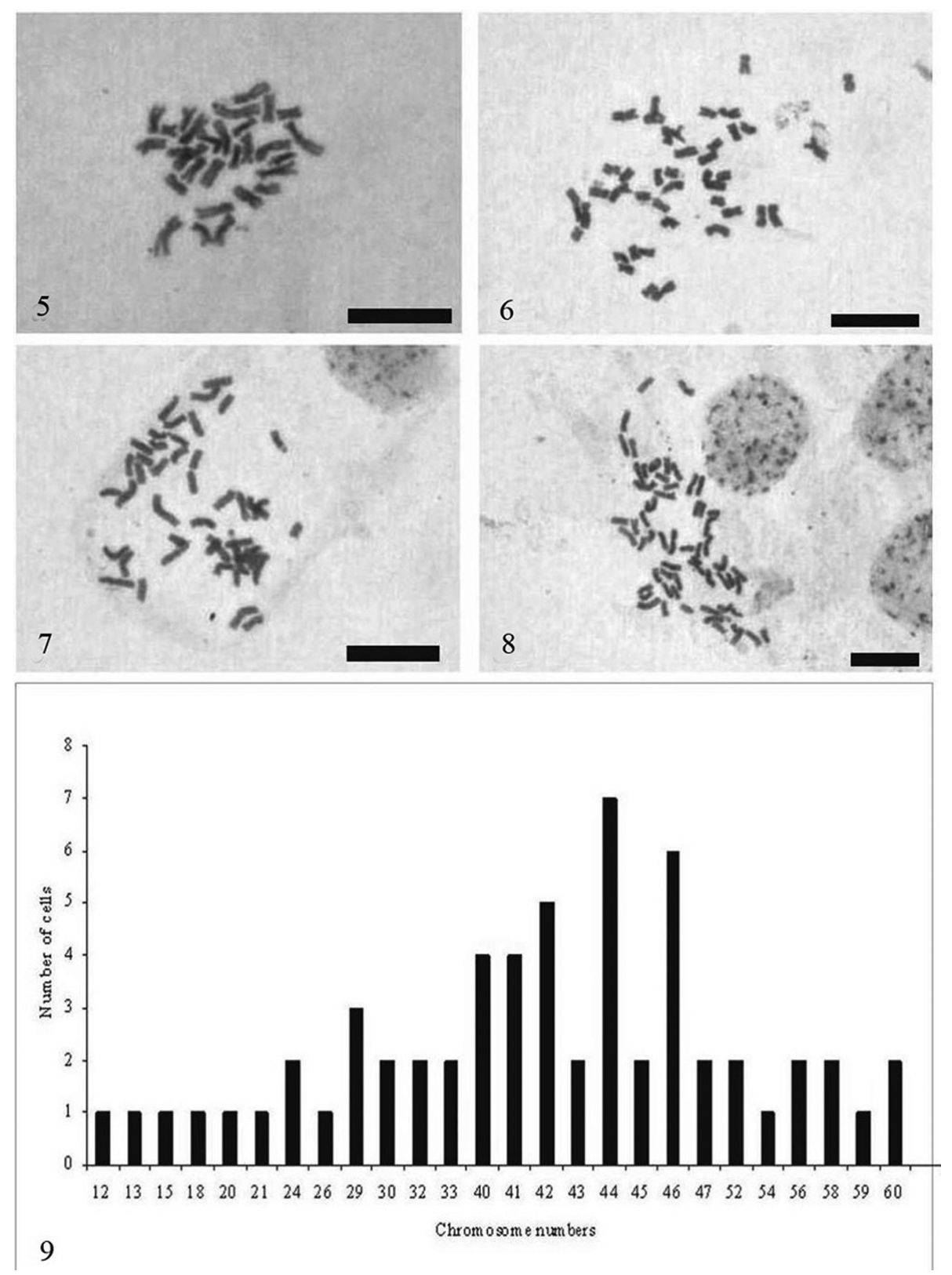

Figs. 5-9 - Mixoploidy in cells of La3-linalool. Fig. 5: $2 n=29$. Fig. 6: $2 n=42$. Fig. 7: $2 n$ $=46$. Fig. $8: 2 \mathrm{n}=60$. Fig. 9: Number of metaphase cells with different chromosome numbers observed in one La3 linalool individual. Scale bars $=10 \mu \mathrm{m}$ for all figures.

(Table II). However, meiotic irregularities were not observed in meiosis II.

On the other hand, $91.1 \%$ of La2-carvone cells presented abnormalities both at meiosis I and II (Table II). The chromosome abnormalities were examined in 399 pollen mother cells. It was possible to observe different chromosome associations in PMC at diakinesis, including cells with univalents, bivalents and mul- tivalents chromosomes (Fig. 10). Early disjunction of chromosomes in metaphase I and II (Table II, Figs. 11 and 14, respectively), bridges and fragments in anaphase I (Table II, Fig. 12), lagging chromosomes in telophase I (Table II), cells with asynchronic nuclei (Table II, Fig. 13), tetrads with lost chromosomes, monads (Table II, Fig. 15) and dyads were observed. Monads cells were the most frequent among the abnormal cells (84.2\%). 
TABLE II

\begin{tabular}{c|c|c|c}
$\begin{array}{c}\text { Number of cells with meiotic abnormalities and pollen viability } \\
\text { means of La1-citral, La2-carvone and La3-linalool. }\end{array}$ \\
\hline \multirow{2}{*}{ Cell stage } & \multicolumn{3}{|c}{ Chemotypes } \\
\cline { 2 - 4 } & La1-citral & La2-carvone & La3-linalool \\
\hline Diakinesis & 9 & 4 & 96 \\
Metaphase I & 9 & 12 & 21 \\
Telophase I & 9 & 10 & 15 \\
Metaphase II & 0 & 3 & 6 \\
Tetrad & 9 & 2 & 90 \\
Monads & 3 & 336 & 0 \\
Abnormal cells (A) & 39 & 367 & 228 \\
Normal Cells (B) & 243 & 32 & 45 \\
Total (A+B) & 282 & 399 & 273 \\
Abnormalities (\%) & 13.8 & 91.1 & 83.5 \\
Pollen viability & $0.82 \mathrm{a}$ & $0.52 \mathrm{~b}$ & $0.35 \mathrm{c}$ \\
\hline
\end{tabular}

Means followed by the same letters did not differ significantly according to Skott-Knott test $(\mathrm{p}=0.05)$.

The La3-linalool showed $83.5 \%$ of cells with meiotic irregularities (Table II). In this chemotype, 273 cells were analyzed and a large number of abnormalities were found. Chromosome associations in diakinesis were observed in $35.2 \%$ of abnormal cells (Table II). Cells with univalents, trivalents and quadrivalents were the most frequent and represent, nearly $73 \%$ of altered cells in prophase I. Univalent (Fig. 16); chromosome chains including several chromosomes translocation rings of four chromosomes (Figs. 17 and 18, respectively), early chromosomes at metaphase I (Table II, Fig. 19), lagging chromosomes in anaphase I (Table II, Fig. 20) and telophase II with lost chromosomes (Table II, Fig. 21) were observed.

Pollen viability also varied among cytotypes. We identified $82.0 \%$ of viable pollen in La1-citral, $52.0 \%$ in La2-carvone, and 35.0\% in La3-linalool (Table II).

\section{RAPD ANALYSIS}

As an initial step, a total of 47 arbitrary 10-mer primers were first screened. All primers amplified L. alba DNA, and $33(70.5 \%)$ of that, were polymorphic. Several patterns of bands were revealed for different primers. Bands showed an average of $968.41 \mathrm{bp}$ ranging from 249bp (OPC-02) to 3062bp (OPA-05). A minimum of 2 (OPA-13 and OPG-16) and a maximum of 12 (OPA09 and OPB-03) unambiguously amplified bands were generated, with an average of 6.3 bands per primer. Out of 208 scored bands, 33 bands (15.86\%) were monomorphic for all genotypes analyzed, and 175 bands $(84.14 \%)$ were polymorphic in L. alba accessions. Figure 22 illustrates the electrophoresis profiles obtained with primers OPC-11 and OPF-10. The high proportion of polymorphic loci reveals intraspecific variation among $L$. alba chemotypes. Genetic distances were calculated for each chemotype to evaluate the intraspecific diversity among them (Table III). The average genetic distances were similar among La1 and La2 (0.02 and 0.03, respectively). La3-linalool showed the highest intraspecific genetic distance (0.44). The variations among La1-La2, La1-La3 and La2-La3 were $0.58,0.40$ and 0.43 , respectively (Table III). The dissimilarity coefficient was used to cluster the data using UPGMA method in a dendrogram (Fig. 23). Lippia alba chemotypes showed a clear separation from each other. Two main groups were formed (Group I with La1 and La3 chemotypes, and Group II with La2 and La3 chemotypes).

TABLE III

Genetic distance means among $L$. alba chemotypes: La1-citral, La2-carvone and La3-linalool.

\begin{tabular}{c|c|c|c}
\hline & La1 & La2 & La3 \\
\hline La1 & 0.02 & & \\
La2 & 0.58 & 0.03 & \\
La3 & 0.40 & 0.43 & 0.44 \\
\hline
\end{tabular}




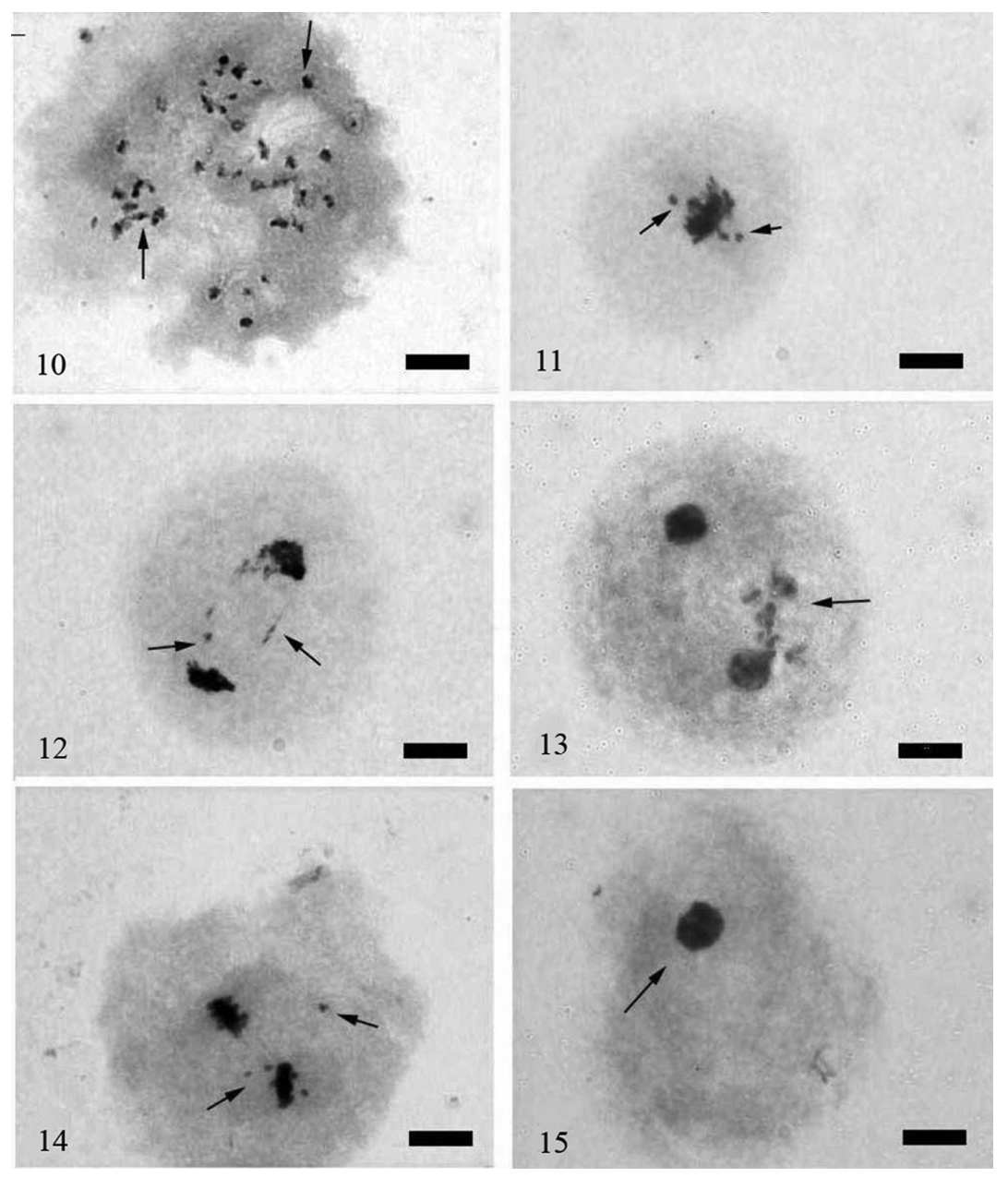

Figs. $10-15-$ Meiotic abnormalities of $\operatorname{La} 2(2 n=4 x=60)$. Fig. 10: Bivalent and trivalent at diakinesis (arrows). Fig. 11: Early disjunction of chromosomes in metaphase I (arrows). Fig. 12: Bridges and fragments in telophase I (arrows). Fig. 13: Assinchronic nuclei (arrow). Fig. 14: Early chromosomes in metaphase II (arrows). Figure 15: Monad (arrow). Scale bars $=10 \mu \mathrm{m}$ for all figures.

\section{DISCUSSION}

The chromosome number of $L$. alba has been previously described as $2 \mathrm{n}=30$ (Bose and Choudhy 1960, Brandão et al. 2007). In the present study we observed different chromosome numbers for different accessions (chemotypes) of Lippia alba collected from Brazil. Plants with $2 \mathrm{n}=30$ for La-1, $2 \mathrm{n}=60$ for La-2, and chromosome numbers ranging from $2 n=12$ to $2 n=60$ for La-3 in the same individual were observed. According to King et al. (2006), the presence of more than one chromosome number in a cellular population is defined as mixoploidy, so La-3 can be considered a mixoploid.
This is the first report of this chromosome variation among accessions of $L$. alba. The occurrence of different chromosome numbers within the same species was also previously reported in other species (Ková and Nzbergová 2006, Srivastavai et al. 2007, Hodálová et al. 2007). Nonetheless, the rate at which these cytotypes arise and their fate in local mixed-cytotype populations are not well understood. These chromosomal variations raise the question whether these cytotypes are genetically separated and whether they can be distinguished morphologically. Studies on the cytotypes that are in the same can provide insights into the nature of interactions among genotypes, the genetic basis of their 
16
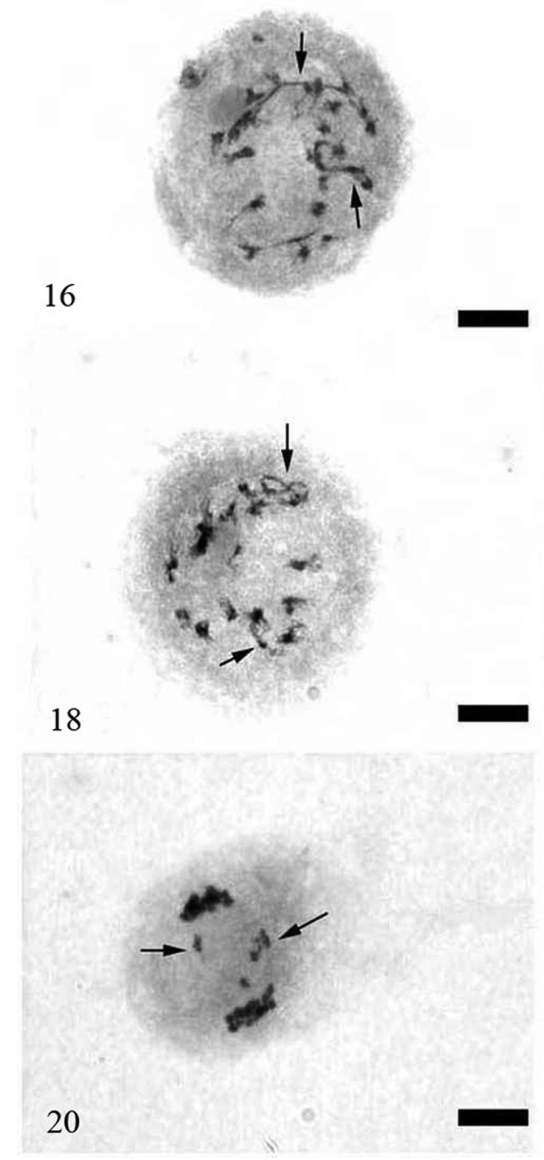

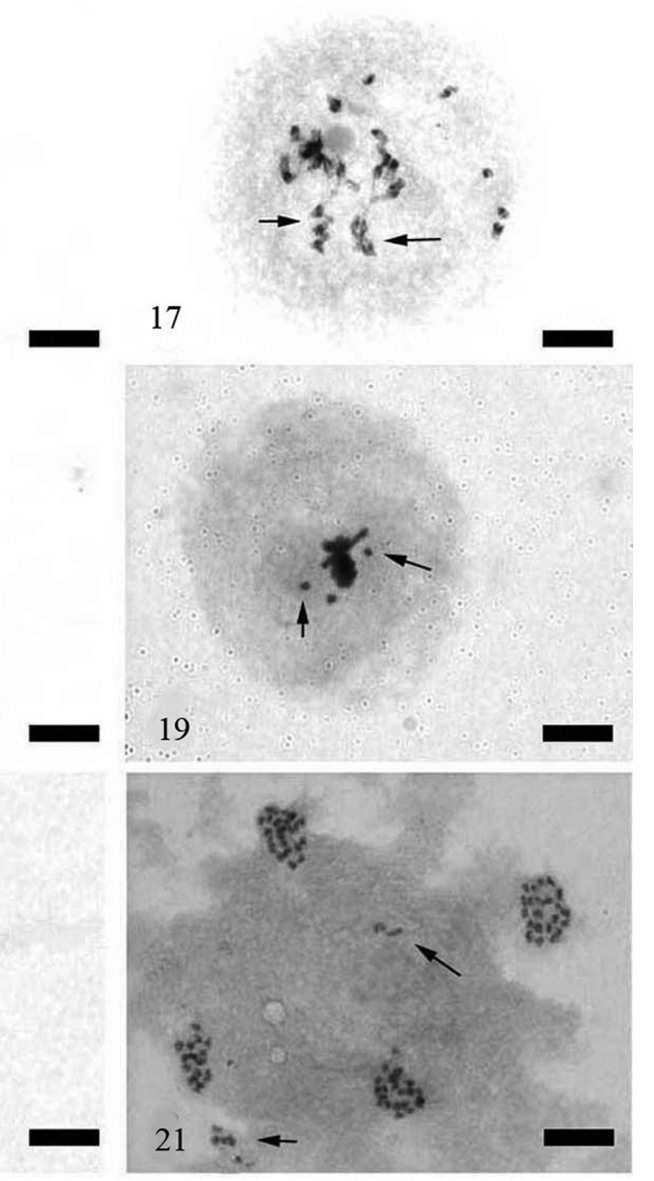

Figs. $16-21-$ Meiotic abnormalities in La3 $(2 n=12$ to 60$)$. Fig. 16: Univalent and chromosome chains including several chromosomes at diakinesis (arrows). Fig. 17 and 18: Univalent, multivalent and translocation ring at diakinesis (arrows). Fig. 19: Early chromosomes at metaphase I (arrows). Figs. 20 and 21: Anaphase I and telophase II with lost chromosomes, respectively (arrows). Scale bars $=10 \mu \mathrm{m}$ for all figures.

differences, and the mechanisms and strength of reproductive isolation that has evolved as a consequence (Harrison and Rand 1989).

Polyploidization has long been recognized as a prominent mechanism of speciation in plant evolution (Stebbins 1950). It is a common phenomenon in plants and it is estimated to occur in $47-70 \%$ of angiosperm species (Soltis et al. 2004). Polyploid species often form aggregates of several different cytotypes (Leitch and Bennett 1997). Existence of different cytotypes requires not only a mechanism enabling the origin of the cytotype, but also a mechanism that would allow its survival and spread. In the genus Lippia, although cytotypes were not yet described, the majority of species showed chromosome numbers smaller than $2 n=30$. The smallest diploid chromosome number described for this genus is $2 n=20$, suggesting that the basic chromosome number for the genus is smaller than ten (Viccini et al. 2006).

Considering the occurrence of a polyploidy among these three cytotypes of $L$. alba, studies about the reproductive aspects of these plants are very important to understand the evolution dynamics. Until now, meiotic studies were done only in L. alba plants (Brandão et al. 2007) that exhibit $2 n=30$ chromosomes and a diploid and regular chromosome behavior. The occurrence of trivalent and quadrivalent associations in La2carvone and La3-linalool observed in the present study reinforce the autopolyploid derivative or hybrid origin 
OPC-11

P $123456789 \mathrm{P}$

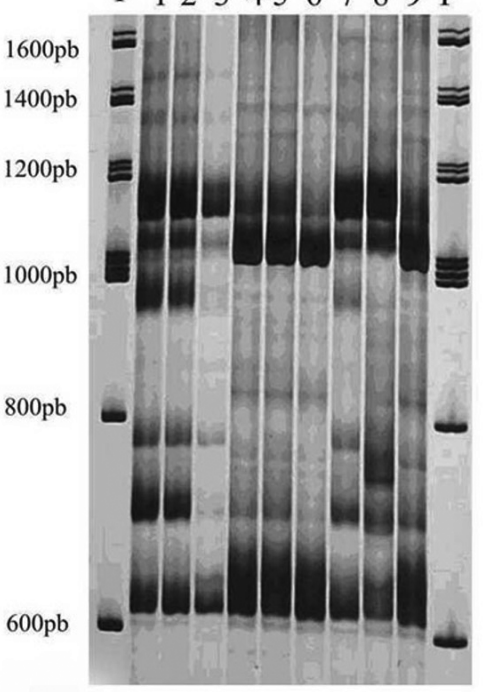

OPF-10

P 12234566789 P

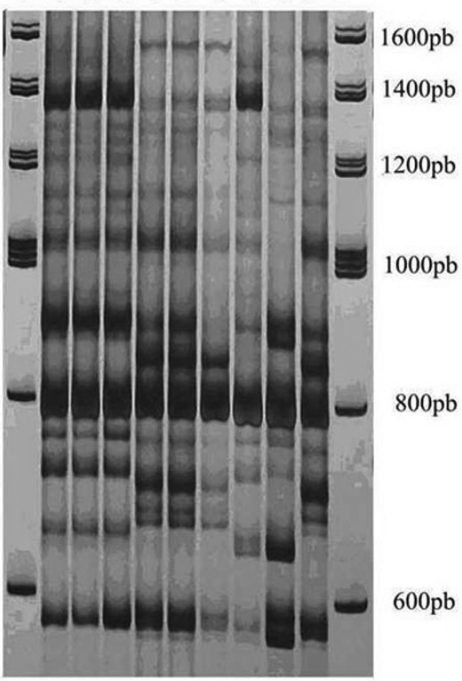

22

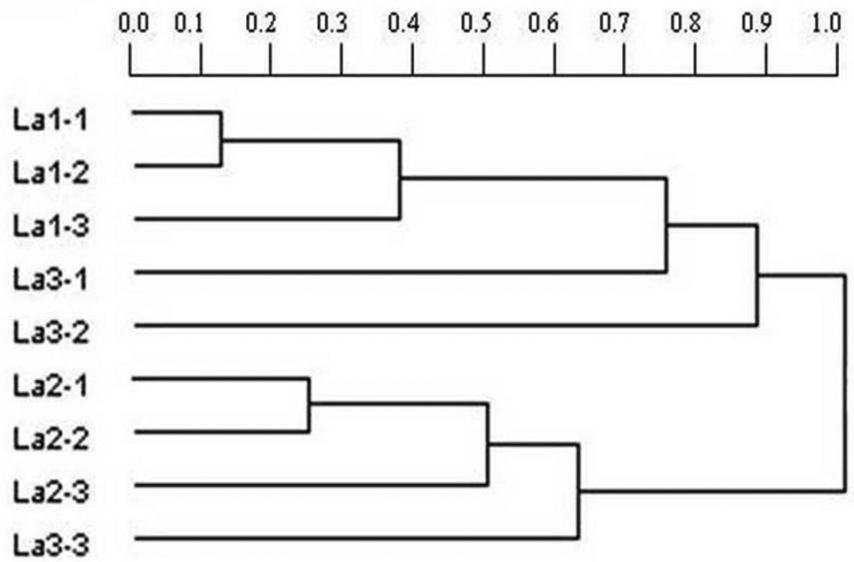

23

Figs. 22-23 - Fig. 22: RAPD bands obtained by OPC-11 and OPF-10 primers: 1, 2, 3 (La1-citral); 4, 5, 6 (La2-carvone) and 7, 8, 9 (La3-linalool); P = DNA ladder standards. Fig. 23: UPGMA clustering of $L$. alba chemotypes based on RAPD markers; La1-1, La1-2 and La1-3 (La1 citral); La2-1, La2-2, La2-3 (La2-carvone); La3-1, La3-2, La3-3 (La3-linalool).

among the parents with similar genome. The presence of univalents during diakinesis is also expected as a consequence of random associations of homologous chromosomes in polyploids (Singh 1993) and can lead to tetrads with chromosome loss, monads and dyads. Low viability of pollen and low seed production were also common in polyploids mainly until their genomic stabilization (Stte- bins 1950, 1971). Meiotic abnormalities, polyploidy and mixoploidy can explain the low viability of pollen and the low seed production in L. alba since they can induce the production of unbalanced gametes. In spite of that, the specimens studied do not show problems in reproducing via asexual mode (data not shown), which help their survival. According to Otto and Whitton (2000), 
asexual reproduction is among the most common shifts in the reproductive system that can be correlated to the occurrence of polyploidy. Moreover, changes in developmental rates in polyploids may affect the likelihood of the establishment of these plants. Together, these observations can also justify the slow growth and the weak appearance observed in La3-linalool chemotypes. In addition, only La1- citral and La2-carvone produced seeds (data not shown), which also helps to understand the major genome stabilization of these genotypes.

Changes of chromosome numbers and behavior observed among these three $L$. alba accessions strikingly affect their reproduction and hinder the mating among them, resulting in genomic (pre-zygotic) reproductive isolation and, therefore, in the origin of new botanic forms. As is commonly known, chromosomal variation affects population structures, genetic component of populations and possibly reproductive isolation among different species, accessions or cytotypes (Okada 1999, Husband 2004).

The nuclear DNA content can also be directly associated with different chromosome numbers, and, with haploid genome total length. The results indicate that La2-carvone $(3.42 \mathrm{pg})$ could be a consequence of a polyploidization event. However, La2-carvone showed only $83.8 \%$ of additional DNA when compared to La1citral $(1.86 \mathrm{pg})$, and a proportional increase of DNA content was not found. If $\mathrm{La} 2$ was really originated from polyploidization of La1, the absence of this proportionality might be attributed to the partial DNA loss of La2 genome after polyploidization. Furthermore, the difference observed between La1-citral and La2-carvone karyotypes suggests a genome rearrangement that could be contributing to DNA loss in these polyploid plants. The decrease in the size of polyploidy genomes in comparison with a correspondent diploid was also observed in other species (Baack et al. 2005, Pecinka et al. 2006), but mechanisms that lead to DNA loss are still poorly understood. These phenomena can occur due to genome rearrangements, transposon activations, elimination of specific sequences and unequal homologous recombination (Leitch and Bennett 2004).

The origin of chromosome number variation observed in La3-linalool is not clear. It is possible that La3 chemotype was formed from a hybrid origin between
La1 and La2. As mentioned before, the difference in cell cycle and DNA amount can contribute to chromosomal instability and mixoploidy in La3 individuals. The variation in chromosome number was observed with both methodologies (cellular dissociation and squash), and was confirmed by flow cytometric data.

Nuclear DNA content reveals that this chemotype shows the DNA content from 2.05 pg to $3.41 \mathrm{pg}$. Many authors have demonstrated the importance of CV (coefficient of variance) of G1 peak to obtain a better DNA estimate (Marie and Brown 1993, Galbraith et al. 2002). Values close to $3 \%$ were considered good and have been considered a critical parameter to estimate the DNA content in plants (Marie and Brown 1993, Galbraith et al. 2002, Loureiro et al. 2006). Excellent coefficients of variance were observed for $\mathrm{La} 1$ and $\mathrm{La} 2$. The $\mathrm{CV}$ value of 5.54 observed for La3 is higher than the others and corroborates the existence of cells with different chromosome numbers in the same individual. This result indicates that the mixoploidy and chromosomal elimination occur at foliar and radicular tissues. Many reasons could explain the elimination of chromosomes, such as differences in timing of essential mitotic processes due to asynchronous cell cycles, asynchrony in nucleoprotein synthesis leading to a loss of the most retarded chromosomes, formation of multipolar spindles, separation of genomes during interphase and metaphase, parent-specific inactivation of centromeres and degradation of alien chromosomes by host-specific nuclease activity (Kim et al. 2002, Germand et al. 2005). Since natural hybridizations are common in the Lippia genus (Sanders 2001), mixoploidy may be a consequence of the hybridization between $L$. alba and closely related species. After interspecific fertilization, two different parental genomes can be combined within one nucleus, and this new genomic constitution may result in intergenomic conflicts leading to genetic and epigenetic reorganization and elimination of chromosomes (Germand et al. 2005).

In addition to cytogenetic and flow cytometric analysis, RAPD markers have been used for genetic analysis since they allow the study of accumulated genetic differences that are important at various taxonomic levels (Ruas et al. 2005). This technique constitutes a powerful tool for studying genetic variability and polyploidy 
of natural populations (Jorgensen et al. 2003), and has also been applied in plant biology to study the taxonomy and biogeography of closely related taxa (Landergott et al. 2001). In L. alba, clusters of La1-La3 and La2-La3 were obtained and could be explained by the presence of mutual bands among them, probably as a consequence of the mixoploid condition of the La3 chemotype. Remarkably high genetic distance was also observed among individuals of La3, which confirms the variation observed by cytogenetic and flow cytometric analysis. On the other hand, the lowest genetic distance was obtained among individuals of La1, which posses $2 n=30$ and the minor percentage of abnormalities in meiotic cells.

Polyploidy has a creative role in plant evolution, and speciation via polyploidy is probably one of the predominant modes of sympatric speciation in plants (Otto and Whitton 2000). In addition, polyploidy can act on the evolution of morphology and reproductive characteristics, metabolic pathways and other significant features for adaptation and speciation (Adams and Wendel 2005). Chromosomal rearrangement is an efficient process that reduces gene flow, which may also contribute to reproductive isolation and speciation (Rieseberg 2001).

Our findings confirm the genetic divergence among these three L. alba chemotypes, indicating that they might belong to different biological units. The data revealed that La1-citral, La2-carvone and La3-linalool showed not only different chemical compositions, but also different chromosome constitutions, reproductive behaviors, DNA contents and molecular marker profiles. Phenotype variation among $L$. alba chemotypes regarding response to rooting, size and texture of leaves, size and color of flowers were also reported by Tavares et al. (2004). The existence of cytotypes in L. alba brings a new possibility of studying natural populations of this medicinal plant where chemotypes and earlier changes in polyploid genome can be easily observed. Other cytogenetic techniques, such as chromosome banding and fluorescent in situ hybridization, are interesting tools to investigate the genomic relationships among these chemotypes and to elucidate their possible origins. Moreover, future studies including morphological, biochemical and ecological data should be considered to precisely define their taxonomic status.

\section{ACKNOWLEDGMENTS}

We thank Dr. Suzana Guimarães Leitão of Universidade Federal do Rio de Janeiro (UFRJ) for plant accessions; and Dr. Fátima Regina Gonçalves Salimena of Universidade Federal de Juiz de Fora (UFJF) for plant identification. This work was sponsored by Brazilian research financial agencies: Fundação de Amparo à Pesquisa do Estado de Minas Gerais (FAPEMIG), Coordenação de Aperfeiçoamento de Pessoal de Nível Superior (CAPES) and Conselho Nacional de Desenvolvimento Científico e Tecnológico (CNPq).

\section{RESUMO}

Análises citogenéticas, de viabilidade do pólen, do conteúdo de DNA nuclear e marcadores RAPD foram empregadas no estudo de três quimiotipos de Lippia alba (Mill.) (Verbenaceae) visando contribuir para o entendimento da variação genética entre os mesmos. Diferentes níveis de ploidia e indivíduos mixoploides foram observados. Este trabalho compreende o primeiro relato de diferentes números cromossômicos (citótipos) em L. alba. Os números cromossômicos dos quimiotipos La2-carvona e La3-linalol sugerem que eles sejam poliploides. A análise da citometria de fluxo mostrou um aumento do conteúdo de DNA nuclear que não foi diretamente proporcional à variação no nível de ploidia. A análise de agrupamento baseada nos marcadores RAPD demonstrou que La3-linalol compartilha marcadores genéticos com La1-citral e La2-carvona. A análise mostrou que a maior parte da variação genética de La3linalol pode ser consequência da mixoploidia. Nossos dados indicam que a reprodução sexual entre os três quimiotipos parece improvável, sugerindo o início de isolamento reprodutivo. Os resultados demonstraram que a análise cromossômica, a quantificação do DNA nuclear estimado e os marcadores RAPD constituem excelentes ferramentas para detecção de variação genética entre quimiotipos de L. alba.

Palavras-chave: quimiotipo, citogenética, citótipo, conteúdo de DNA, RAPD, Lippia alba.

\section{REFERENCES}

AdAms KL AND Wendel JF. 2005. Polyploidy and genome evolution in plants. Current Opinion in Plant Biol 8: 135-141.

AlEXANDER MPA. 1980. A versatile stain for pollen, fungi, yeast and bacteria. Stain Technol 55: 13-19. 
BAACK EJ, Whitney KD AND Rieseberg LH. 2005. Hybridization and genome size evolution: timing and magnitude of nuclear DNA content increases in Helianthus homoploid hybrid species. New Phytol 167: 623-630.

Bassole IHN, Ouattara As, Nebie R, Ouatara CAT, Kabore ZI AND Traore SA. 2003. Chemical composition and bacterial activities of the essential oils of Lippia chevalieri and L. multiflora from Burkina Faso. Phytochemisty 62: 209-212.

BiAsi LA And Costa G. 2003. Propagação vegetativa de Lippia alba. Cienc Rural 33: 455-459.

Bose RB And Choudhy JK. 1960. Cytological studies in L. alba (Mill) N.E. Br. Bull Bot Soc Bengal 14: 71-72.

BRADSHAW AD. 2006. Unraveling phenotypic plasticity why should we bother? New Phytol 170: 644-648.

BRANDÃo AD, VicCini LF, SALIMENA FRG, VANZELA ALL AND RecCo-Pimentel SM. 2007. Cytogenetic characterization of Lippia alba and Lantana camara (Verbenaceae) from Brazil. J Plant Res 120: 317-321.

Caixeta ET and Carvalho CR. 2001. An improved cytogenetic method for maize pachytene chromosomes. Cytologia 66: 173-176.

CARVAlHo CR AND SARAiva LS. 1993. A new heterochromatin banding pattern revealed by modified HKG banding technique in maize chromosomes. Heredity 70 : 515-519.

CAVAllini A And Natali L. 1990. Nuclear DNA variability within Pisum sativum Leguminosae): cytophotometric analysis. Plant Syst Evol 173: 173-185.

Cruz CD. 2001. 'Programa Genes - Versão Windows, aplicativo computacional em genética e estatística' UFV Viçosa-MG, Brasil.

Dolezel J, Greilhuber J AND SudA J. 2007. Flow cytometry with plant cells. Wiley-VCH, $454 \mathrm{p}$.

DOYLE JJ AND DOYLE JL. 1987. Isolation of plant DNA from fresh tissue. Focus 12: 13-15.

Galbraith DW, Lambert G, Macas J And Dolezel J. 2002. Analysis of nuclear DNA content and ploidy in higher plants. In: JOHN PR ET AL. (Eds), Current protocols in cytometry. New York: Wiley, New York, USA, p. 75-85.

Germand D, Rutten T, Varshney A, Rubtsova M, Prodanovic S, Brüb C, Kumelehn J, Matzk F AND HouBEN A. 2005. Uniparental chromosome elimination at mitosis and interphase in wheat and pearl millet crosses involves micronucleus formation, progressive heterochromatinization and DNA fragmentation. The Plant Cell 17: 2431-2438.

HARRISON RG AND RAND MD. 1989. Mosaic hybrid zones and the nature of species boundaries. In: DANIEL O AND JOHN AE (Eds), Speciation and its consequences. Sinauer, Sunderland, Massachusetts, p. 111-133.

Hennebelle T, Sahpaz S, Dermont C, Joseph H and BAILleul F. 2006. The essential oil of Lippia alba: analysis of samples from French overseas departments and review of previous works. Chem Biodivers 3: 1116-1125.

Hennebelle T, Sahpaz S, Gressier B, Joseph H and BAilleul F. 2008. Antioxidant and neurosedative properties of polyphenols and iridoids from Lippia alba Phytother Res 22: 256-258.

HodÁlová I, CRUlich V, HoRová L, VAlachovic M AND MARHOLD K. 2007. Ocurrence of tetraploid and octoploid cytotypes in Senecio jacobaea ssp. Jacobaea (Asteraceae) in Pannonia and the Carpathians. Bot J Linn Soc 153: 231-242.

Husband BC. 2004. Chromosomal variation in plant evolution. Am J Bot 91: 621-625.

Jorgensen JL, Stehlik I, Brochmann C AND Conti E. 2003. Implications of ITS sequences and RAPD markers for the taxonomy and biogeography of the Oxytropis campestris and O. artica (Fabaceae) complexes in Alaska. Am J Bot 90: 1470-1480.

Jump AS and Penuelas J. 2005. Running to stand still: adaptation and the response of plants to rapid climate change. Ecol Lett 8: 1010-1020.

Kim NS, Armstrong KC, Fedak G, Ho K and Park NI. 2002. A microsatellite sequence from the rice blast fungus (Magnaporthe grisea) distinguishes between the centromeres of Hordeum vulgare and H. bulbosum in hybrid plants. Genome 45: 165-174.

King RC, Stansfield WD and Mulligan PK. 2006. A Dictionary of Genetics. Oxford. New York, 609 p.

KovÁ TM AND NzBergová SM. 2006. Distribution and ecology of cytotypes of the Aster amellus aggregates in the Czech Republic. Ann Bot 98: 845-856.

Kumar P AND DutT B. 1989. Cytogenetic basis of breeding system in some verbenaceous species. Cytologia 54: $347-353$.

LANDERgott U, Holderegger R, Kozlowski G AND SCHNELLER JJ. 2001. Historical bottlenecks decrease genetic diversity in natural population of Dryopteris cristata. Heredity 87: 344-355.

Leitch IJ And BennetT MD. 1997. Polyploidy in angiosperms. Trends Plant Sci 2: 420-476. 
LeitCh IJ AND BennetT MD. 2004. Genome downsize in polyploids plants. Biol J Linn Soc 82: 651-663.

LeVAn A, Fredga K And SAndberg AA. 1964. Nomenclature for centromeric position in chromosomes. Hereditas 52: 201-220.

Loureiro J, Rodriguez E, Dolezel J And SAntos C. 2006. Comparison of four nuclear isolation buffers for plant DNA flow cytometry. Ann Bot 98: 679-689.

MARIE D AND BROWN SC. 1993. A cytometric exercise in plant DNA histograms, with $2 \mathrm{C}$ values for 70 species. Biol Cell 78: 41-51.

NEI M AND LI W. 1979. Mathematical model for studying genetic variation in terms of restriction endonucleases. Proc Natl Acad Sci 76: 5269-5273.

Noel F, Machon N And Porcher E. 2007. No genetic diversity at molecular markers and strong phenotypic plasticity in populations of Ranunculus nodiflorus, an endangered plant species in France. Ann Bot 99: 12031212.

OHRI D. 1998. Genome size variation and plant systematics. Ann Bot 82: 75-83.

OKADA H. 1999. Chromosomal evolution of Angiosperms. In: Kunio I AND Peter HR (Eds), Evolution and diversification of Land Plants. Springer-Verlag, New York, USA, p. 209-220.

Otto SP And Whitton J. 2000. Polyploid incidence and evolution. Annu Rev Genet 34: 401-437.

Pecinka A, Suchankova P, Lysak MA, Travnicer B AND Dolezel J. 2006. Nuclear DNA content variation among central European Koeleria taxa. Ann Bot 98: $117-122$.

Rieseberg LH. 2001. Chromosomal rearrangements and speciation. Trends Ecol Evol 6: 351-358.

Ruas CF, VAnzela ALL, SAntos MO, Fregonezi JN, Ruas PM, Matzenbacher Ni AND Aguiar-PereCIN MLR. 2005. Chromosomal organization and phylogenetic relationships in Hipochaeris species (Asteraceae) from Brazil. Genet Mol Biol 28: 129-139.

SANDERS RW. 2001. The genera of Verbenaceae in the Southeastern United States. Harvard P Bot 5: 303-358.

SAXENA R AND CHANDRA A. 2006. RAPD and cytological analysis and histological changes caused by moisture stress in Dichanthium annulatum accessions. Cytologia 71: 197-204.
SCHEINER SM. 1993. Genetic and evolution of phenotypic plasticity. Annu Rev Ecol Syst 24: 35-68.

SHEIDAI M, SHAHRIARI ZH, ROKNEIZADEH H AND NoORMOHAmmadi Z. 2007. RAPD and cytogenetic study of some tetraploid cotton (Gossypium hirsutum L) cultivars and their hybrids. Cytologia 72: 77-82.

SingH RJ. 1993. Plant Cytogenetics. Boca Raton: CRC Press, $463 \mathrm{p}$.

Soltis DE, Soltis PE AND TATE JA. 2004. Advances in the study of polyploidy since plant speciation. New Phytol 161: 173-191.

Srivastavai J, Ranadei AS And Khare PB. 2007. Distribution and threat status of the cytotypes of Pteris vittata L. (Pteridaceae) species complex in India. Curr Sci 93: 81-85.

StebBIns GL. 1950. Variation and evolution in plants. New York: Columbia University Press, 643 p.

StebBins GL. 1971. Chromosome evolution in higher plants. London: Edward Arnold, 216 p.

TAVARES ES. 2003. Estudos integrados em Lippia alba (Verbenaceae) - uma planta de interesse econômico e medicinal. Thesis (Doctorade in Plant Physiology) - Federal Rural University of Rio de Janeiro.

Tavares ES, Julião LS, Lopes D, Bizzo HR, Lage CLS AND LEITÃo SG. 2004. Análise do óleo essencial de folhas de três quimiotipos de Lippia alba (Mill) NEBr (Verbenaceae) cultivados em condições semelhantes. Rev Bras Farmacog 15: 1-5.

Theis L AND LerdaU M. 2003. The evolution of function in plant secondary metabolites. Int J Plant Sci 164: S93S102.

Viccini lf, Pierre PMO, Praça MM, Costa DCS, Romanel EC, Sousa SM, Peixoto PHPP And SALIMENA FRG. 2006. Chromosome numbers in the genus Lippia (Verbenaceae). Plant Syst Evol 256(4): 171-179.

West-Eberhard MJ. 1989. Phenotypic plasticity and the origins of diversity. Annu Rev Ecol Syst 20: 249-278.

Williams JG, Kubelik AR, LivaK KJ, Rafalski LA AND TINGEY SV. 1990. DNA polymorphism amplified by arbitrary primers are useful as genetic markers. Nucleic Acids Res 18: 6531-6535.

Zoghbi MGB, Liz AIR And Ramos LS. 1998. Essential oil of Lippia alba (Mill.) NE Br growing wild in the Brazilian Amazon. Flavour Frag J 13: 47-48. 